\title{
PERS DAN JURNALISTIK DA'WAH DALAM MEMBANGUN OPINI PUBLIK
}

\author{
P-ISSN: 2085-4536 | E-ISSN: 2721-7183 \\ Link: https://jurnal-stidnatsir.ac.id/index.php/dakwah/article/view/60 \\ DOI : https://doi.org/10.38214/jurnaldawahstidnatsir.v3i01.60 \\ Dikirim: 01-05-2020 Direview: 01-05-2020 Diterbitkan: 06-05-2019
}

\author{
IMAM TAUFIK ALKHOTOB \\ imamtaufik@stidnatsir.ac.id \\ STID Mohammad Natsir, Indonesia
}

\begin{abstract}
ABSTRAK
Tujuan Penelitian: Penelitian ini ingin mengungkap pers dan jurnalistik dakwah dalam membangun opini public. Metode Penelitian: Kualitatif. Hasil Penelitian: Pers dan dunia jurnalisme adalah alat pembentukan opini publik. Karena bersifat alat, maka dia dapat digunakan oleh siapa dan untuk kepentingan apa saja. Oleh karena itu, Pers dan kegiatan jurnalistik tidak bisa dipisahkan dari idiologi pemilik pers dan ideologi penulisnya. Keduanya dapat menentukan kemana arah opini akan dibangun. Dalam kontek ini, da'wah tidak boleh terpaku hanya menjadikan verbal sebagai alat menyapa ummat. Da'wah harus memiliki kesiapan dalam menggunakan pena sebagai penyampai pesan da'wah. Karena pada dasarnya, kerja da'wah adalah upaya membangun opini publik yang berbasis pada ajaran Islam yang mulia. Dengan pembentukan opini public yang benar tentang da'wah maka ajaran Islam akan lebih dapat diterima oleh public dengan cara pandang yang benar pula.
\end{abstract}

Keyword: Da’wah, pers, jurnalistik, pesan

\section{PENDAHULUAN}

Peradaban masa kini sering disebut sebagai peradaban masyarakat informasi. Informasi menjadi suatu komoditi primer bahkan sumber kekuasaan. Informasi dapat dijadikan alat untuk membentuk pendapat publik (public opinion) yang mempengaruhi dan mengendalikan pikiran, 
sikap, dan perilaku manusia. Hingga pada akhirnya, muncul sebuah anggapan bahwa sumber baru kekuasaan saat ini adalah "informasi di tangan banyak orang" (the new source of power is information in the hand of many), dan siapa yang menguasai media massa maka dialah pengendali atau penguasa dunia. ${ }^{1}$

Tak heran jika sarana atau media informasi terus berkembang begitu pesat demi meraih kepentingan di atas. Media-media tersebut hadir merepresentasikan maksud, tujuan, dan target-target tertentu. Bagi khalayak ramai, kehadiran sebuah informasi tentu bisa menjadi sesuatu yang positif namun juga sebaliknya. Informasi terkadang membuat seseorang bergerak secara gegabah tanpa terlebih dahulu melakukan proses tabayyun yang cukup. Persoalannya menjadi semakin rumit ketia sebuah informasi atau berita negatif mendapatkan tempatnya di benak pembaca, mempengaruhi dan mengendalikan gerak serta prilaku mereka. Inilah yang menjadi dasar analisa Lippmann. Menurut Lippmann, masyarakat menerima fakta bukan sebagaimana adanya, akan tetapi apa yang mereka anggap sebagai fakta; "kenyataan fatamorgana" atau "lingkungan palsu". Distorsi-distorsi tidak hanya datang dari faktor emosional dan kebutuhan ego saja, tetapi juga dari stereotip-stereotip, gambaran yang kita miliki tentang para tokoh figur publik, dan produk benda-benda. ${ }^{2}$

Sejatinya, penggunaan media informasi sebagai alat komunikasi dapat dikategorikan ke dalam lima bagian; ${ }^{3}$ alat penerangan massa, alat pendidikan massa, alat mempengaruhi massa, alat hiburan, dan digunakan perorangan atau kelompok. Pada pembahasan ini, persoalan media sebagai alat untuk mempengaruhi massa lebih dominan. Bahkan ia mampu mencakup secara umum. Proses mempengaruhi masa justeru dapat dilakukan melalui penerangan, edukasi, hiburan atau sebuah kelompok atau orang tertentu.

${ }^{1}$ Asep Syamsul M. Romly, Jurnalistik Dakwah; Visi dan Misi Dakwah bil Qalam, Bandung: Remadja Rosdakarya, 2003, hal. 13 hal. xxii

${ }^{2}$ Walter Lippmann, Opini Umum, Jakarta: Yayasan Obor Indonesia, 1994,

${ }^{3}$ S.M. Siahaan, Komunikasi; Pemahaman dan Penerapannya, Jakarta: BPK Gungung Mulia, 1991, hal. 7 
Sejak bermulanya era komunikasi melalui media cetak yang ditandai dengan penemuan mesin cetak pada tahun1456 oleh Johan Gensfleisch (lebih terkenal dengan Gutenberg) di Jerman, ia berubah secara cepat menjadi suatu kekuatan tersendiri di tengah-tengah percaturan kepentingan manusia di dunia. Maka pada tulisan ini penulis hendak mengkaji sejauhmana kekautan informasi khususnya media cetak (pers) mampu menjadi sebuah kekuatan publik yang efektif memberikan pengaruh ditengah-tengah masyarakat. Kaitannya dengan amal da'wah, kajian ini hendak memotret urgensi antara pers dan kegiatan jurnalistik yang berperan mengemban misi da'wah tersebut.

\section{HASIL DAN DISKUSI}

\section{Pers dan Jurnalistik}

Pers. Istilah pers berasal dari bahasa Belanda yang dalam bahasa Inggris artinya press. Secara harfiah pers berarti "cetak" dan secara maknawiah berarti penyiaran secara tercetak atau publikasi secara dicetak (printed publications). Pers juga dapat difahami sebagai sebuah kegiatan publikasi yang meggunakan media cetak seperti surat kabar, majalah dan jenis media cetak lainnya. ${ }^{4}$ Dalam perkembangannya pers mempunyai dua pengertian, yakni pers dalam pengertian luas dan pers dalam arti sempit. Pers dalam arti luas meliputi segala penerbitan, bahkan termasuk media elektronik, radio siaran, dan televisi siaran. Sedangkan pers dalam arti sempit hanya terbatas pada media massa cetak yaitu surat kabar, majalah, buletin dan yang semisalnya. Kenyataan bahwa radio dan televise termasuk dalam lingkup pers ialah jika diadakan jumpa pers (press confrerence) maka yang datang untuk meliput adalah semua media. ${ }^{5}$

Ada anggapan kurang tepat dikalangan akademisi bahwa jurnalistik sama dengan pers atau keduanya bisa dipertukarkan. Sesungguhnya tidak demikian, karena jurnalistik menunjukkan kepada proses kegiatan sedang pers berhubungan dengan media. Secara etimologi jurnalistik berasal dari bahasa Perancis; journ (catatan/laporan harian) yang secara sederhana diartikan sebagai kegiatan pencatatan atau

4 Totok Djuroto, Manajemen Penerbitan Pers, Bandung: Remaja Rosdakarya, 2002, hal. 5

${ }^{5}$ Onong Uchjana Effendy, Ilmu Komunikasi; Teori dan Praktek, Bandung Remadja Rosdakarya, 2002, hal. 145 
pelaporan setiap hari. Dengan demikian, jika digabungkan kedua istilah diatas dengan sebutan umum "jurnalistik pers" maka artinya adalah proses kegiatan mencari, menggali, mengumpulkan, mengolah, memuat, dan menyebarkan berita melalui media berkala pers yaitu surat kabar, tabloid atau majalah kepada khalayak seluas-luasnya dengan secepatcepatnya. ${ }^{6}$

Pada dasarnya, jurnalistik juga dapat dibedakan ke dalam beberapa bentuk. Diantara bentuk-bentuk Jurnalistik tersebut diantaranya; Jurnalistik Media Cetak (newspaper and magazine journalism) meliputi jurnalistik surat kabar harian, mingguan, tabloid harian, tabloid mingguan, dan majalah. Selain itu terdapat pula, Jurnalistik Media Elektronik Auditif (radio broadcast journalism) yaitu yang berkaitan dengan kegiatan radio siaran. Terakhir adalah Jurnalistik Media Audiovisual (television journalism) yang berkatian dengan televisi siaran atau jurnalistik media on line (internet). ${ }^{7}$ Khusus jurnalistik di wilayah media cetak, maka ia dipengaruhi oleh dua faktor utama yakni faktor verbal dan visual. Faktor verbal sangat menekankan pada kemampuan kita memilih dan menyusun kata dalam rangkaian kalimat dan paragrap yang efektif dan komunikatif. Sementara faktor visual, menunjukkan pada kemampuan kita dalam menata, menempatkan, mendesain tata letak atau hal-hal yang menyangkut segi perwajahan. ${ }^{8}$ Antara kedua faktor ini tak dapat dipisahkan. Informasi atau pesan yang dikemas dengan gaya bahasa menarik akan menimbulkan efek yang jauh lebih besar jika mendapatkan desain yang menarik pula.

Kembali kepada persoalan pers. Secara umum pers adalah lembaga kemasyarakatan (social institution). Sebagai lembaga kemasyarakatan pers merupakan subsistem kemasyarakatan tempat ia berada bersama-sama dengan subsistem lainnya. Dengan demikian maka pers tidak hidup secara mandiri tetapi mepengaruhi dan dipengaruhi oleh lembaga-lembaga kemasyarakatan lainnya. ${ }^{9} \mathrm{Hal}$ ini secara tidak langsung

${ }^{6}$ AS Haris Sumadiria, Jurnalistik Indonesia; Menulis Berita dan Feature, Bandung: Sembiosa Rekatama Media, 2006, hal. 1

${ }^{7}$ AS Haris Sumadiria, Jurnalistik Indonesia; Menulis Berita dan Feature, hal. 4

${ }^{8}$ AS Haris Sumadiria, Jurnalistik Indonesia; Menulis Berita dan Feature, hal. 4

${ }^{9}$ Onong Uchjana Effendy, Ilmu Komunikasi; Teori dan Praktek, Bandung Remadja Rosdakarya, 2002, hal. 146 
karena pers lahir dalam sebuah ruangan waktu yang tidak kosong. Artinya, founding pers di setiap lembaga pers adalah manusia-manusia yang memiliki dan meyakini akan sebuah nilai dan misi tertentu dalam aktifitasnya.

Hingga saat ini pers tetap dianggap sebagai the fourth estate setelah tiga lembaga kekuasaan lainnnya yang berputar dalam pemerintahan; eksekutif, legislative, dan yudikatif. Tiga lembaga ini mampu mengendalikan masa karena kekuasaan formalnya, sedangkan pers mampu mempengaruhi masa karena daya persuasinya yang kuat dan pengaruhnya yang besar kepada masyarakat. Menurut Graber hal ini terjadi karena media mampu menawarkan model-model perilaku. ${ }^{10}$ Dalam skala jangkauan yang luas, maka pers media cetak khususnya dapat menggerakkan manusia untuk melakukan sesuatu dan berbuat untuk sesuatu. Keresahan Napoleon Bonaparte adalah contohnya. Di masanya, ia harus mengekang dan menyensor sejumlah media massa dan mengurangi jumlah media dari 13 menjadi 4 saja plus larangan mengkritik pemerintah. Ia juga membunuh lebih dari 70 jurnalis dengan hukuman penggal guillotine hanya karena persoalan ketidakcocokan pemberitaan. Kebencian Nazi terhadap bangsa Yahudi juga terlihat begitu besar salah satunya adalah sebab keberhasilan surat kabar Der Stuemmer pada penerbitan Mei 1934 ketika menunjukkan darah orang-orang Jerman yang tak bersalah mengalir ke dalam piring-piring orang Yahudi. ${ }^{11}$ Kebencian yang berlarut-larut itu bahkan tetap diperingati hingga hari ini.

Selanjutnya, pertanyaan yang mungkin muncul adalah sejauhmana sesungguhnya sebuah tulisan yang dimuat melalui kegiatan jurnalistik pers mampu memberikan efek kepada pembaca. Terlebih lagi jika efek tersebut mendorong banyak orang secara efektif untuk mensepakati sebuah wacana hingga kepada tingkat opini bersama. Hal ini dapat dijelaskan bila kita memahami proses komunikasi massa, antara sebuah penyampaian pesan dan efek pesan tersebut.

\section{Pesan Teks dalam Media Cetak}

10 Asep Saeful Muhtadi, Jurnalistik Pendekatan Teori dan Praktik, Bandung: Remadja Rosdakarya, 2000. hal. 49

${ }^{11}$ Nurudin, Komunikasi Propaganda, Bandung: Remadja Rosdakarya, 2002, hal. 35 
Persoalan teks atau tulisan sesungguhnya menarik untuk dicermati. Tokoh-tokoh filsafat seperti Plato dan Sokrates misalnya, tidak menganggap penting peran tulisan. Bagi Plato, ia justeru memiliki kehawatiran logosentris yang muncul bersama asumsi adanya sumber pengetahuan otentik, murni, benar serta ada cara untuk meyampaikan kebenaran itu. Melalui tulisan penyampaian logos dapat dilangsungkan oleh siapapun, bahkan juga oleh mereka yang tidak memiliki wewenang. Inilah yang ditakutkan. Dalam hal ini Plato lebih mementingkan kepada kemampuan jiwa untuk mengingat sebuah fakta, informasi dan kebenaran lainnya. Sementara Socrates, ia juga tak terlihat memiliki perhatian terhadap teks. Ia bahkan menganggap tulisan tidak memiliki keakuratan peristiwa. Tulisan tak lebih dari sebuah lukisan yang menggeneralisasikan makhluk hidup menjadi makhluk yang tak hidup. Karena sampai kapapun mereka akan tetap diam jika ditanya. ${ }^{12}$

Namun tidak demikian halnya dalam pandangan Aart van Zoest. Baginya "teks tak pernah lepas dari ideologi dan memiliki kemampuan untuk memanipulasi pembaca ke arah suatu ideologi." ${ }^{13}$ Dr. Phil. Astrid S. Susanto dalam bukunya "Komunikasi Massa" turut serta dalam pandangan di atas. Ia menjelaskan bahwa semua media yang dimiliki swasta maupun pemerintah sebenarnya merupakan aparatur ideologi (Ideological State Apparatus (ISA)). Maka dengan sendirinya semua alat komunikasi akan berusaha untuk mengemukakan apa yang menurut dirinya adalah terbaik. ${ }^{14}$

Jika ungkapan ini benar, maka sangat dimungkinkan dalam sebuah kebudayaan dan peradaban yang saling bertukar informasi terjadi apa yang disebut dengan "perang teks" (war of tex). Perang teks disini menjadi bagian dari perang informasi itu sendiri. Sebagaimana disebutkan di atas, bahwa teks memuat sejumlah pesan yang tidak berdiri sendiri. Bahkan pesan yang dilahirkan dari sebuah media berasal dari tahapantahapan tertentu (editing, layout, dll). Maka tidak jaran terjadi pemberitaan atau informasi yang bias.

12 Alex Sobur, Analisis Teks Media; Suatu Pengantar untuk Analisis Wacana, Analisis Sembiotik, dan Analisis Framing, Bandung: Remaja Rosda Karya, 2001, hal. 50-52

13 Alex Sobur, Analisis Teks Media; Suatu Pengantar untuk Analisis Wacana, Analisis Sembiotik, dan Analisis Framing, hal. 60

${ }^{14}$ Astrid S. Susanto, Komunikasi Massa 2, Jakarta: Penerbit Bina Cipta, 1986, hal. 1 
Dalam pandangan Alex Sobur pada bukunya "Analisis Teks Media" ia menegaskan bahwa pada dasaranya bias berita terjadi karena media massa tidak berada diruang vakum. Media sesungguhnya berada di tengah realitas sosial yang sarat dengan berbagai kepentingan, konflik dan fakta komleks lagi beragam. ${ }^{15}$ Untuk itulah kita perlu mendapatkan logika yang tepat dibalik sebuah penyampaian pesan yang dilakukan oleh media.

Dari sudut pandang ilmu komunikasi Prof. Dr. H.A.W. Widjaja menjelaskan bahwa pesan itu sendiri adalah keseluruhan dari apa yang disampaikan oleh komunikator. Pesan ini mempunyai inti berupa tema yang sebenarnya menjadi pengarah di dalam upaya merubah sikap dan tingkah laku komunikan. ${ }^{16}$ Sementara dalam studi media, ada tiga pendekatan yang digunakan sebagai sebuah usaha untuk menjelaskan isi media. ${ }^{17}$

Pertama, pendekatan politik-ekonomi (the political-economy approach). Pendekatan ini berpendapat bahwa isi media lebih ditentukan oleh kekuatan-kekuatan (eksternal) diluar pengelolaan media yaitu; ekonomi dan politik. Pengelola media dipandang bukan sebagai entitas yang aktif, dan ruang lingkup pekerjaan mereka dibatasi berbagai struktur yang mau ridak mau memaksanya untuk memberitakan fakta dengan cara tertentu. Bentuk media seperti ini biasanya memiliki kedekatan dengan aparatur Negara atau partai politik disuatu Negara. Kedua, pendekatan organisasi

15 Alex Sobur, Analisis Teks Media; Suatu Pengantar untuk Analisis Wacana, Analisis Sembiotik, dan Analisis Framing, hal. 29

${ }^{16}$ H.A.W. Widjaja, Ilmu Komunikasi; Pengantar Studi, Jakarta: PT Rineka Cipta, 2000, hal. 32. Prof. Widjaya kemudian membagi pesan ke dalam; a) Pesan Informatif. Bersifat memberikan keteragan-keterangan (fakta-fakta), kemudian komunikan mengambil kesimpulan dan keputusan sendiri. biasanya berhasil dan cocok untuk kalangan cendekiawan. b) Pesan Persuasif. Berisikan bujukan, yaitu membangkitkan pengertian dan kesadaran manusia bahwa apa yang kita sampaikan akan memberikan perubahan sikap, tetapi dengan kesadaran sendiri (tanpa paksa). Perubahan tersebut diterima atas kesadaran sendiri. c) Pesan Koersif. Penyampaian pesan yang bersifat memaksa dengan menggunakan sanksi-sanksi apabila tidak dilaksanakan. Bentuk yang terkenal dari penyampaian model ini adalah agitasi dengan penekanan-penekanan yang menimbulkan tekanan pada batin dan ketakutan di kalangan publik. Koersif dapat berbentuk perintah-perintah, instruksi, dan sebagainya. Penulis melihat bahwa pesan yang bersifat propaganda belum masuk dalam kategori di atas. Kenyataannya, pesan seringkali tidak mencerminkan ketiga kategori di atas bahkan cenderung bersifat propaganda atau propokatif.

17 Agus Sudibyo, Politik Media dan Pertarungan Wacana, Yogyakarta: LKiS, 2006, hal. 2-7 
(organizational approaches). Pendekatan ini justeru melihat pengelola media sebagai pihak yang aktif dalam proses pembentukan dan produksi berita. Dalam pendekatan ini, berita dilihat sebagai hasil dari mekanisme yang ada dalam ruang redaksi. Praktik kerja, profesionalisme, dan tata aturan yang ada dalam ruang organisasi adalah unsure-unsur dinamik yang mempengaruhi pemberitaan. Dalam hal ini media dianggap otonom untuk menentukan apa yang boleh dan tidak boleh, apa yang baik atau buruk, dan apa yang layak atau tidak layak untuk diberitakan. Ketiga, pendekatan kulturalis (culturalist approach). Pendekatan ini merupakan gabungan antara pendekatan ekonomi politik dan pendekatan organisasi. Di sini, proses berita dipandang sebagai suatu mekanisme yang rumit yang melibatkan faktor internal media dan eksternal media. Media pada dasarnya memang mempunyai mekanisme untuk menentukan pola dan aturan organisasi, tetapi berbagai pola yang dipakai untuk memaknai peristiwa tersebut tidak dapat dilepaskan dari kekuatan-kekuatan ekonomi politik di luar diri media. Pendekatan kurturalis meniscayakan terjadinya dua hal yang berbeda. Ada hubungan yang rumit antara sumber berita dan seorang jurnalis. Kedua-duanya saling membutuhkan, tidak saling mengkooptasi secara langsung. Namun memang pada akhirnya praktik jurnalistik melahirkan pemberitaan yang lebih dominan pada kekautan politik yang hegemonik. ${ }^{18}$

Dari sisi bagaimana media massa melahirkan fakta, Adian Husaini juga mencoba menggambarkan bagaimana sebuah pesan yang berisikan fakta-fakta menjadi kabur ditengah perjalanan. Lihat bagan berikut ini.

\begin{tabular}{|c|c|c|c|}
\hline Fakta sebenarnya & $\begin{array}{l}\text { institusi media massa } \\
\text { fakta semu III }\end{array}$ & fakta semu I & public \\
\hline
\end{tabular}

${ }^{18}$ Penjelasan ini diambil dari pendapt Brain McNair. Lihat, Brain McNair, News and Journalism in the UK: A Texbook, London and New York: Routledge, 1994, hlm. 39-38 
Dari gambar di atas, terlihat bahwa institusi media massa berperan menjadi alat untuk memecah fakta menjadi sesuatu yang bukan aslinya. Inilah yang disebut bahwa media massa apapun termasuk media cetak tidak dapat dilepaskan dari kepentingan-kepentingan sebagaimana dijelaskan diatas. Sementara itu, fakta semu yang ditelan oleh publik secara terus menerus dapat menjadi agen pemecah berikutnya yang dapat turut serta membuat fakta baru. ${ }^{19}$

Persoalan lain yang turut menentukan corak isi sebuah media adalah persoalan sumber informasi, berita atau fakta. Sebagian jurnalis terkadang terjebak kepada sumber yang tidak otoritatif sehingga menyebabkan data yang ditampilkan tidak akurat. Maka tidak jarang seorang jurnalis harus melakukan reinterpretasi terhadap sebuah fakta yang didapatinya agar sesuai dengan konsumsi public. Berdasarkan materi yang digunakan sebagai bahan informasi. Maka informasi dapat dibedakan ke dalam dua katagori; ${ }^{20}$ Pertama, apa yang disebut dengan Realitas Sosiologis (empiris). Realitas sosiologis diperoleh berdasarkan pengalaman lansung atau pengamatan langsung seseorang terhadap suatu peristiwa nyata. Bahan baku yang membangun realitas sosiologis dari suatu peristiwa bersifat faktual. Artinya, fakta peristiwa tersebut dapat dilacak di tempat kejadian atau berdasarkan kesaksian orang lain. Kedua, Realitas Psikologis. Realitas psikologis merupakan hasil rekaan pikiran seseorang (interpretasi) terhadap peristiwa nyata, sedang ia sendiri tidak mengalami atau menyaksikan peristiwa tersebut. Bahan baku yang membangun realitas psikologis semata-mata bersumber pada pandangan atau pendapat seseorang terhadap suatu masalah.

\section{Pembentukan Opini Publik}

Ditinjau dari pendekatan ilmu media, maka Isi dari media cetak sesungguhnya dapat di katagorikan kedalam dua hal; fakta dan opini. ${ }^{21}$ Fakta di sini adalah sesuatu yang bisa dilihat, diraba, dan dirasakan oleh setiap orang. Oleh karena itu, laporan faktual adalah laporan wartawan dari lapangan berdasarkan sesuatu yang dilihatnya atau kesaksian orang

19 Adian Husaini, Penyesatan Opini; Sebuah Rekayasa Mengubah Citra, Jakarta: Gema Insani Press, 2002, hal. xxvii

20 Ashadi Siregar dan Rondang Pasaribu, Bagaimana Mengelola Media Korporasi Organisasi, Yogyakarta: Peberbit Kanisius, 2000, hal. 67

21 Aceng Abdullah, Press Relations; Kiat Berhubungan dengan Media Massa, Bandung: Remaja Rosdakarya, 2001, hal. 14 
lain. Artinya ia betul-betul terjadi. Isi media cetak yang berdasarkan fakta adalah; berita. Karena bersifat faktual biasanya berita selalu dianggap objektif. Opini adalah pendapat atau pandangan tentang sesuatu. Karena itu opini bersifat subjektif karena pandangan atau penilaian seseorang dengan lainnya selalu berbeda, meski didasari fakta yang sama. Termasuk opini diantaranya; artikel, tajuk rencana, karikatur, pojok, dan surat pembaca. Sementara itu, antar Fakta dan opini terdapat apa yang disebut feature (karangan khas). Feature bukan karya fiksi melainkan tulisan faktual bergaya sastra sehingga amat menarik untuk dibaca dan terkadang mampu mengarahkan emosi pembacanya. ${ }^{22}$

Ditinjau dari sudut ilmu komunikasi maka efek atau hasil akhir dari proses penyampaian pesan dapat ditinjau ke dalam tiga bagian; ${ }^{23}$

a. Personal Opinion. Disebut juga dengan pendapat pribadi. Ia adalah sikap dan pendapat seseorang terhadap sesuatu masalah tertentu.

b. Public Opinion. Diartikan sebagai pendapat umum. Pengertiannya adalah penilaian sosial mengenai sesuatu hal yang penting dan berarti atas dasar pertukaran pikiran yang dilakukan individu secara sadar dan rasional.

c. Majority Opinion. Pendapat sebagian terbesar dari public atau masyarakat. Inilah misalnya yang harus dicapai oleh kampanye pemilu.

Dalam hal ini opini publik dapat dikatakan sebagai target dalam penyampaian pesan. Akan tetapi, opini publik seperti apakah yang memiliki efektifitas ?. Oleh karenanya sebagian pakar komunikasi membedakan antara public opinon dan general opinion. Public opinion lebih tepat diartikan sebagai "pendapat khalayak" atau "anggapan khalayak." Opini publik menurut Clyde L. King pakar publisistik pada Universitas Pensylvania adalah penilaian sosial (social judgement) mengenai suatu masalah. Opini publik bukanlah kata sepakat dari orang-orang publik.

${ }^{22}$ Feature bisa mengandung unsure berita atau tidak. Feature berita adalah feature yang terpengaruh unsure waktu, yang berhubungan dengan peristiwa hangat yang menarik perhatian masyarakat. Biasanya cepat lekang dimakan waktu. Sementara feature human interest tidak punya nilai berita. Ia tidak memberikan informasi mengenai kepentingan umum yang vital. Lihat, Bambang Bujono (Ed.), Seandainya Saya Watawan Tempo, Jakarta: ISAI dan Yayasan Alumni TEMPO, 1997, hal. 100

${ }^{23}$ H.A.W. Widjaja, Ilmu Komunikasi; Pengantar Studi, Jakarta: PT Rineka Cipta, 2000, hal. 38 
Opini publik dapat merupakan mayoritas pendapat, tapi bukan mayoritas pendapat yang dapat dihitung secara numeric menurut jumlah. Andaikan ada 49 persen dari suatu populasi menyatakan pendapat dengan tegas dan kuat, sedangkan 51 persen menyatakan pendapat dengan lemah dan setengah-setengah, maka opini yang 49 persenlah akan muncul sebagai kekuatan. Karena itu opini publik bukanlah numerical majorty, melainkan effective majority. ${ }^{24}$

Peran media sejatinya adalah untuk membentuk effective majority itu. Opini publik yang memiliki sifat efektif akan memiliki pengaruh yang kuat ditengah-tengah masyarakat. Ia tidak hanya mengubah cara pandang seseorang terhadap sebuah persoalan, bahkan sangat mungkin mengarah kepada tahap perubahan prilaku sekalipun. Namun demikian sebuah opini publik yang efektif tidaklah terjadi begitu saja. Ketika sebuah opini dipublikasikan, maka proses perjalanan ke arah opini publik dapat mengandung unsur-unsur berikut; ${ }^{25}$

a. Kemungkinan terjadinya pro dan kontra (sebelum tercapai konsekwensus)

b. Melibatkan lebih dari seorang

c. Dinyatakan, artinya terbuka dan dapat dimonitori oleh publik

d. Mengadakan tanggapan yang pro maupun kontra (favourable)

Jika merujuk kepada teori "pers bebas", maka pada tahapan tanggapan antara pro dan kontra itulah akan muncul seleksi kebenaran fakta secara bertahap dan tidak secara langsung. Dalam hal ini Walter Lippmann menyebutkan, "Teori pers bebas menyatakan bahwa kebenaran akan muncul dari pelaporan yang bebas dan diskusi yang bebas. Artinya, kebenaran tidak dapat disajikan dengan sempurna dalam segera dalam suatu laporan. ${ }^{26}$

Sebagaimana dijelaskan Ferdinand Tonies dalam karyanya Die Offentlichen Meinung, maka tahapan opini pubik secara umum dapat diuraikan sebagai berikut; ${ }^{27}$

${ }^{24}$ Adian Husaini, Penyesatan Opini; Sebuah Rekayasa Mengubah Citra, hal. xxvii

${ }^{25}$ Astrid S. Susanto, Pendapat Umum, Bandung: Bina Cipta, 1985, hal. 94

${ }^{26}$ David S. Broder, Behind the Fornt Page, a Candid Look at how News is Made, terj. Lilian. T, Jakarta: Pustaka Sinar Harapan, 1996, hal. 421

${ }^{27}$ Nurudin, Komunikasi Propaganda, hal. 56 
a. Die Luftartigen Position. Ini adalah tahapan awal pembentukan opini dimana masing-masing individu meyampaikan opininya ibarat angin ribut dan semrawut.

b. Die Fleissigen Position. Pada tahap ini pembicaraan opini sudah menunjukkan tahap kejelasan dan bisa dianggap pendapatpendapat mulai mengumpul ke arah tertentu

c. Die Festigen Position. Tahap ketiga ini yang menunjukkan bahwa pembicaraan dan diskusi telah mantap dan suatu pendapat telah terbentuk dan siap untuk dinyatakan. Atau dengan kata lain siap untuk diyakini kebenarannya setalah melalui perdebatan tajam.

\section{Pers, Jurnalistik dan Visi Da'wah}

Baru-baru ini kita mengenal sebuah istilah baru dalam dunia jurnalisitk dengan sebutan; jurnalistik da'wah atau jurnalistik Islami. Istilah yang dipopulerkan oleh Asep Syamsul M. Romly, dalam bukunya "Jurnalistik Dakwah; Visi dan Misi Dakwah bil Qalam" menjelaskan tentang sebuah keharusan da'wah yang diorganisir lewat media tulis menulis seperti buku, surat $\mathrm{kabar}^{28}$, majalah, dan lain-lain. Aktifitas jurnalistik yang dilakukan oleh seorang muslim seharusnya adalah aktifitas da'wah itu sendiri. Oleh karenanya, Jurnalistik Islami dapat dirumuskan sebagai suatu proses meliput, mengolah, dan menyebarluaskan berbagai peristiwa dengan muatan nilai-nilai kebenaran yang sesuai dengan ajaran Islam, khususnya yang menyangkut agama dan umat Islam. ${ }^{29}$

Istilah lain yang kemudian dimunculkan adalah da'wah bil qalam. Aep Kusnawan dalam bukunya "Berdakwah Melalui Tulisan" menyebutkan istilah itu dengan merujuk kepada setiap aktifitas yang berbasis penulisan di media apapun. Ia melihat bahwa da'wah melalui tulisan merupakan bagian integral dari bidang kajian dakwah. Ia adalah salah satu unsur dakwah yaitu media dakwah. Karena ia merupakan media maka ukuran utama penggunaannya adalah keefektifan dan keefesienan. Semakin efektif dan efesien suatu media, maka ia akan semakin dipertimbangkan orang lain untuk menjadi pilihan. Oleh karena itulah

${ }^{28}$ Surat kabar paling tidak memiliki empat posisi yaitu sebagai; lembaga sosial, lembaga ekonomi, produk informasi, dan media informasi. Lihat, Ana Nadhya Abrar, Teknologi Komunikasi Prespektif Ilmu Komunikasi, Yogyakarta: LESFI, 2003, hal. 43

${ }^{29}$ Asep Syamsul M. Romly, Jurnalistik Dakwah; Visi dan Misi Dakwah bil Qalam, Bandung: Remadja Rosdakarya, 2003, hal. 35-36 
tulisan dipandang sebagai sesuatu yang efektif untuk menyampaikan pesan da'wah. ${ }^{30}$

Dalam ruang informasi yang begitu luas dimana era keterbukaan menjadi hal yang disepakati secara umum maka jurnalistik islami atau jurnalistik da'wah harus memiliki eksistensi yang diandalkan. Hanya saja, problematika itulah yang kini sedang diidapi oleh kaum muslimin. Kebutuhan informasi masyarakat muslim belum diimbangi dengan lembaga informasi media yang mampu betul-betul memiliki keberpihakan terhadap agenda besar kaum muslimin. Sejumlah media yang eksis saat ini tak jarang cenderung menonjolkan eksistensi kelompok atau ormas tertentu. Demikian pula dengan para jurnalis muslimnya. Aktifitas kerja yang mereka lakukan seringkali terikat dengan kepentingan lembaga tempat mereka berkerja. Secara tak langsung mereka telah larut dalam garis edar yang tak lagi merepresentasikan tugasnya sebagai wartawan muslim. Asep Samsul dalam bukunya yang lain "Jurnalitsik Praktis" menyebutkan setidaknya ada lima peranan yang harus dambil oleh seorang jurnalis muslim yaitu; ${ }^{31}$

a. Sebagai pendidik (mu'addib), yaitu menjelaskan fungsi edukasi yang Islami.

b. Sebagai pelurus informasi (musaddid). Setidaknya ada tiga hal yang harus diluruskan oleh jurnlais muslim. Pertama, informasi tentang ajaran dan umat Islam. Kedua, informasi tentang karya-karya atau prestasi umat Islam. Ketiga, lebih dari itu, jurnalis muslim dituntut untuk mampu menggali informasi kondisi umat Islam di seluruh penjuru dunia

c. Sebagai pembaharu (mujaddid). Yakni penyebar faham pembaharuan akan pemahaman dan pengamalan ajaran Islam.

d. Sebagai pemersatu (muwabhid). Yakni menjadi jembatan yang mempersatukan umat Islam.

e. Sebagai pejuang (mujahid). Yaitu jurnalis muslim yang memiliki ruh untuk memperjuangkan Islam dan membelanya. Melalui media massa jurnlais muslim berusaha keras untuk membentuk opini umum yang mendorong penegakan nilai-nilai Islam.

2004, hal. 5

${ }^{30}$ Aep Kusnawan, Berdakwah lewat Tulisan, Bandung: Mujahid Press,

${ }_{31}$ Asep Syamsul M. Romli, Jurnalistik Praktis (untuk pemula), Bandung: Remaja Rosdakarya, 2001, hal. 89 
Lima peran di atas jika dilakukan secara maksimal dipastikan akan banyak membantu roda informasi yang saat ini berbenturan terus menerus dengan peradaban kuffar.

Di tangan jurnalis muslim diharapkan terbentuk sebuah informasi yang mampu mendorong terciptanya opini publik berdasarkan pada informasi yang diferifikasi tidak hanya berdasarkan teori-teori jurnalistik dan mass media akan tetapi juga berdasarkan pandangan hidup (world view) Islam yang bersumber kepada al Qur'an dan as Sunnah. Oleh karena itu, visi da'wah jurnalitik islami atau jurnalistik da'wah adalah mempersempit ruang gerak media-media berbasis ideologi kuffar yang memiliki kemampuan teknologi dan sumber daya manusia handal. Setidaknya, akan muncul konsumsi media yang berimbang di tengah-tengah masyarakat kita.

\section{KESIMPULAN}

Pers dan dunia jurnalisme adalah alat pembentukan opini publik. Karena bersifat alat, maka dia dapat digunakan oleh siapa dan untuk kepentingan apa saja. Oleh karena itu, Pers dan kegiatan jurnalistik tidak bisa dipisahkan dari idiologi pemilik pers dan ideologi penulisnya. Keduanya dapat menentukan kemana arah opini akan dibangun. Dalam kontek ini, da'wah tidak boleh terpaku hanya menjadikan verbal sebagai alat menyapa ummat. Da'wah harus memiliki kesiapan dalam menggunakan pena sebagai penyampai pesan da'wah. Karena pada dasarnya, kerja da'wah adalah upaya membangun opini publik yang berbasis pada ajaran Islam yang mulia. Dengan pembentukan opini public yang benar tentang da'wah maka ajaran Islam akan lebih dapat diterima oleh publik dengan cara pandang yang benar pula.

\section{DAFTAR PUSTAKA}

Abdullah, Aceng. Press Relations; Kiat Berbubungan dengan Media Massa, Bandung: Remaja Rosdakarya, 2001

Abrar, Ana Nadhya, Teknologi Komunikasi Prespektif Ilmu Komunikasi, Yogyakarta: LESFI, 2003 
Broder, David S. Bebind the Fornt Page, a Candid Look at how News is Made, terj. Lilian. T, Jakarta: Pustaka Sinar Harapan, 1996

Bujono, Bambang (Ed.). Seandainya Saya Watawan Tempo, Jakarta: ISAI dan Yayasan Alumni TEMPO, 1997

Djuroto, Totok. Manajemen Penerbitan Pers, Bandung: Remaja Rosdakarya, 2002

Effendy, Onong Uchjana. Ilmu Komunikasi; Teori dan Praktek, Bandung Remadja Rosdakarya, 2002

Husaini, Adian, Penyesatan Opini; Sebuah Rekayasa Mengubah Citra, hal. xxvii

Kusnawan, Aep, Berdakwah lewat Tulisan, Bandung: Mujahid Press, 2004

Lippmann, Walter. Opini Umum, Jakarta: Yayasan Obor Indonesia, 1994

M. Romli, Asep Syamsul, Jurnalistik Praktis (untuk pemula), Bandung: Remaja Rosdakarya, 2001

Muhtadi, Asep Saeful. Jurnalistik Pendekatan Teori dan Praktik, Bandung: Remadja Rosdakarya, 2000.

Nurudin, Komunikasi Propaganda, Bandung: Remadja Rosdakarya, 2002

Romly, Asep Syamsul M. Jurnalistik Dakwah; Visi dan Misi Dakwah bil Qalam, Bandung: Remadja Rosdakarya, 2003

Siahaan, S.M. Komunikasi; Pemahaman dan Penerapannya, Jakarta: BPK Gungung Mulia, 1991

Siregar, Ashadi dan Rondang Pasaribu. Bagaimana Mengelola Media Korporasi Organisasi, Yogyakarta: Peberbit Kanisius, 2000

Sobur, Alex. Analisis Teks Media; Suatu Pengantar untuk. Analisis Wacana, Analisis Sembiotik, dan Analisis Framing, Bandung: Remaja Rosda Karya, 2001

Sudibyo, Agus, Politik Media dan Pertarungan Wacana, Yogyakarta: LKiS, 2006

Sumadiria, AS Haris. Jurnalistik Indonesia; Menulis Berita dan Feature, Bandung: Sembiosa Rekatama Media, 2006

Susanto, Astrid S. Komunikasi Massa 2, Jakarta: Penerbit Bina Cipta, 1986 
Susanto, Astrid S. Pendapat Umum, Bandung: Bina Cipta, 1985

Widjaja, H.A.W. Ilmu Komunikasi; Pengantar Studi, Jakarta: PT Rineka Cipta, 2000 